Bangladesh J. Bot. 49(4): 975-980, 2020 (December)

\title{
DESICCATION SENSITIVITY OF WILD CASTANEA MOLLISSIMA BLUME DETERMINED BY DIFFERENTIAL SCANNING CALORIMETRY
}

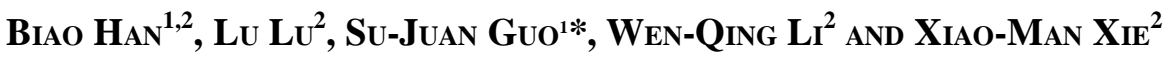 \\ Key Laboratory for Silviculture and Conservation, Ministry of Education, \\ Beijing Forestry University, Beijing 100083, China
}

Keywords: Recalcitrant seed, Desiccation sensitivity, Differential scanning calorimetry, Thermodynamic analysis

\begin{abstract}
Thermal properties of wild Castanea mollissima seeds embryos with different moisture contents, and the optimal moisture contents for cryopreservation were studied. Seeds of similar size and weight $(3.5 \pm 0.3 \mathrm{~g})$ were put in silica gel at 0 to 7 days, embryo moisture content, viability and thermal properties were measured everyday. The results showed that the onset temperature and the crystallization peak of the mean enthalpy decreased with the decrease of embryo moisture content. Exothermic peak disappeared when the seeds were dried for 4 days, with an embryo moisture content of $0.45 \pm 0.15 \mathrm{gH}_{2} \mathrm{O} / \mathrm{g}$ dw. The unfrozen water content $\left(\mathrm{WC}_{\mathrm{u}}\right.$ ) was $0.247 \mathrm{gH}_{2} \mathrm{O} / \mathrm{g} \mathrm{dw}$. The optimal water content was found to be $0.45 \pm 0.15 \mathrm{gH}_{2} \mathrm{O} / \mathrm{g} \mathrm{dw}$, with the survival of $76.2 \%$. Castanea mollissima embryonic axes dehydration needs comprehensive consideration of exothermic peak, unfrozen water content, onset temperature and viability loss.
\end{abstract}

\section{Introduction}

Recalcitrant seeds usually attain maturity with relatively high moisture contents and they are sensitive to dehydration, and cannot be stored in conventional seed banks for long term ( $\mathrm{Li}$ and Pritchard 2009, Walters et al. 2012, Xia et al. 2013). Cryopreservation is a viable strategy for embryo storage of some recalcitrant species (Corredoira et al. 2004, Xia et al. 2014). However, recalcitrant seeds have desiccation sensitive embryos which cannot tolerate sub-zero temperatures at high moisture contents. Hence, in order to do cryopreservation, it is important to know the features of seeds desiccation tolerance, viability and induction of glassy stage.

Differential scanning calorimetry (DSC) is a useful tool for the non-invasive observation of seed tissues, particularly in terms of their thermal behaviour (Walters et al. 2005, Lehner et al. 2006). DSC can be used in determining 'freezable' free water or unfrozen water content (Zoubi and Normah 2015), free water frozen lead to freezing injury during embryo cryopreservation, if desiccation sensitive seeds remove 'freezable' free water, freezing injury will be avoided during cryopreservation.

Castanea mollissima Blume (Chinese chestnut) is a widely distributed species in northern hemisphere (Serdar et al. 2011). In China, chestnut is distributed in 24 provinces, covering an area over $2 \times 10^{7}$ ha, and it is an important economic forest tree, million farmers rely on chestnuts as their main economic source in mountainous areas (Zou et al. 2015). However, Chinese chestnut has desiccation sensitive seeds (Zong and Cai 2010), which makes its germplasm conservation difficult. In the present study, DSC analysis was used to analyze the thermal properties at various moisture contents after the seeds dehydration in silica gel, and to investigate the desiccation sensitive features and the optimal moisture content for cryopreservation.

\footnotetext{
*Author for correspondence: <hanbiaook831228@163.com>. ${ }^{1}$ Beijing Forestry University, Beijing 100083, China;

${ }^{2}$ Shandong Forest Germplasm Resources Center, Jinan, 250102, China.
} 


\section{Materials and Methods}

In September, wild C. mollissima seeds were collected from the mountain area ( N 34 $4^{\circ} 41^{\prime \prime}$, E 107³9'50", altitude 884.6 m. ) of Baoji City, Shanxi Province. After harvest, the seeds were sent to seed bank. The seeds with similar size and weight $(3.5 \mathrm{~g} \pm 0.3 \mathrm{~g})$ were dried in silica gel for various periods $\left(0,1,2,3,4,5,6,7\right.$ day) at ambient temperature $\left(25 \pm 2^{\circ} \mathrm{C}\right)$. Silica gel was dried and changed everyday. After each desiccation period, 23 embryonic axes of the seeds (in triplicates) were randomly sampled and measured. Ten for viability assessment, 3 for DSC and 10 for moisture content determination, the experiment were repeat three times.

Moisture content of the seeds and embryonic axes $\left(\mathrm{gH}_{2} \mathrm{O} / \mathrm{g} \mathrm{dw}\right)$ were gravimetrically determined at the end of each desiccation period, using 10 seeds and 10 embryonic axes, replicated three times and dried to a constant weight in oven at $103^{\circ} \mathrm{C}$ for $17 \mathrm{hrs}$.

Seed viability test was carried out using TTC test. The seeds were cut to seed tissue with embryonic axes inside, 10 seed tissues in $1 \%$ TTC were incubated at $30^{\circ} \mathrm{C}$ for $3 \mathrm{hrs}$. After that, the embryonic axes were excised under anatomic microscope and embryos viability was scored and repeated three times.

The thermal analysis of different embryo moisture contents was undertaken using the DSC of TA company D250 (USA), which incorporates a liquid nitrogen cooling system. 3 embryonic axes samples of different moisture contents were placed in aluminium pans, sealed and weighed on a microbalance. The samples were kept at $30^{\circ} \mathrm{C}$ for $1 \mathrm{~min}$, cooled at the rate of $10^{\circ} \mathrm{C} / \mathrm{min}$ to $-150^{\circ} \mathrm{C}$ for $2 \mathrm{~min}$, and then re-warmed to room temperature (Zoubi and Normah 2015).

The embryonic axes survival and DSC data were analysed by an ANOVA with a least significance difference (Tukey test) post-hoc test, difference at the 0.05 level is considered to be significant. For thermograms analysis, DSC equipment TRIOS V4 software (TA, USA) was used.

\section{Results and Discussion}

Silica gel drying resulted in considerable water loss, but the moisture content decreased in different ratios for different dried days (Table 1). For example, dried for 1 day, the embryo moisture content reduced from $1.59 \mathrm{gH}_{2} \mathrm{O} / \mathrm{g}$ dw to $0.73 \mathrm{gH}_{2} \mathrm{O} / \mathrm{g} \mathrm{dw}$, which decreased $54.1 \%$. However, the seed moisture content only decreased $34.7 \%$, less than the embryo moisture content. The embryo moisture content decrease ratio were 54.1, 15.1, 24.2, 4.3, 15.6, 10.5 and $14.7 \%$ at 1 to 7 days, it shows that embryonic axes water loss was in different ratio from the endosperm.

In the first 4 days, silica gel drying not resulted in remarkable embryonic axes viability loss. After dried for 4 days, the embryo moisture content was reduced from $1.59 \mathrm{gH}_{2} \mathrm{O} / \mathrm{g}$ dw to 0.45 $\mathrm{gH}_{2} \mathrm{O} / \mathrm{g} \mathrm{dw}$ (Table 1), which decreased $71.7 \%$, however, viability of desiccated embryonic axes just reduced from 90.48 to $76.19 \%$, which decreased $15.8 \%$. Survival of dried embryo showed a significant decline after the moisture content reduced to $0.38 \mathrm{gH}_{2} \mathrm{O} / \mathrm{g} \mathrm{dw}$, with the survival of $57.14 \%$. The embryonic axes dried for 7 days showed $47.62 \%$ survival with moisture content of $0.29 \mathrm{gH}_{2} \mathrm{O} / \mathrm{g} \mathrm{dw}$, which proved that the embryonic axes of $C$. mollissima was desiccation sensitive.

Table 1 shows that the onset temperature, peak temperature and enthalpy decreased as the moisture content of the embryo was decreased. The highest value for the mean enthalpy of fresh embryonic axes was $125.02 \mathrm{~J} / \mathrm{g} \mathrm{dw}$, at embryo moisture content of $1.59 \mathrm{gH}_{2} \mathrm{O} / \mathrm{g} \mathrm{dw}$. After desiccation 3 days, mean enthalpy decreased to $0.6 \mathrm{~J} / \mathrm{g} \mathrm{dw}$ and the onset temperature decreased to $-28.95^{\circ} \mathrm{C}$, at a moisture content of $0.47 \mathrm{gH}_{2} \mathrm{O} / \mathrm{g} \mathrm{dw}$ (Table 1). After desiccation for 4 days, the moisture content of embryo decreased to $0.45 \mathrm{gH}_{2} \mathrm{O} / \mathrm{g} \mathrm{dw}$, no peak was observed (Table 1 and Fig. 1).

Freezable water leads to crystallization. Fig.1 ( 0 - 3 days) shows that at relatively higher moisture contents, embryo showed larger exothermic peak, presumably from the crystallization of 
free water. Crystallization peak was observed when the mean moisture content was $0.47 \mathrm{gH}_{2} \mathrm{O} / \mathrm{g}$ $\mathrm{dw}$ or greater, however, it disappeared when the moisture content was below $0.45 \mathrm{gH}_{2} \mathrm{O} / \mathrm{g} \mathrm{dw}$ (Fig. 1,4 day).

The onset temperature is considered to be the starting point of free water crystallization. Table 1 shows that the mean onset temperature decreased from -14.38 to $-28.95^{\circ} \mathrm{C}$, and the mean peak temperature decreased from -14.78 to $-35.09^{\circ} \mathrm{C}$ as the moisture content of the embryo was decreased from $1.59 \mathrm{gH}_{2} \mathrm{O} / \mathrm{g}$ dw to $0.47 \mathrm{gH}_{2} \mathrm{O} / \mathrm{g} \mathrm{dw}$. The onset temperature and peak temperature decreased means the embryonic axes free water became harder to freeze, it is beneficial to seeds (embryos) freezer storage.

Table 1 Moisture content, survival and thermal properties of embryonic axes of Castanea mollissima seed dried in silicone.

\begin{tabular}{|c|c|c|c|c|c|c|}
\hline \multirow{2}{*}{$\begin{array}{l}\text { Seed desicca- } \\
\text { tion time } \\
\text { (day) }\end{array}$} & \multirow{2}{*}{$\begin{array}{l}\text { Seed moisture } \\
\text { content } \\
\left(\mathrm{gH}_{2} \mathrm{O} / \mathrm{g} \mathrm{dw}\right)\end{array}$} & \multirow{2}{*}{$\begin{array}{c}\text { Embryo moisture } \\
\text { content } \\
\left(\mathrm{gH}_{2} \mathrm{O} / \mathrm{g} \mathrm{dw}\right)\end{array}$} & \multirow{2}{*}{$\begin{array}{c}\text { Survival } \\
(\%)\end{array}$} & \multicolumn{3}{|c|}{ Thermal properties } \\
\hline & & & & $\begin{array}{l}\text { Onset } \\
\left({ }^{\circ} \mathrm{C}\right)\end{array}$ & $\begin{array}{l}\text { Enthalpy } \\
(\mathrm{J} / \mathrm{g} \mathrm{dw})\end{array}$ & $\begin{array}{l}\text { Peak temp. } \\
\left({ }^{\circ} \mathrm{C}\right)\end{array}$ \\
\hline 0 & $1.01 \pm 0.09$ & $1.59 \pm 0.24$ & $90.48^{\mathrm{a}}$ & $-14.38 \pm 1.28$ & $125.01 \pm 6.74$ & $-14.78 \pm 0.39$ \\
\hline 1 & $0.66 \pm 0.08$ & $0.73 \pm 0.12$ & $90.48^{\mathrm{a}}$ & $-19.10 \pm 5.79$ & $53.89 \pm 39.80$ & $-19.75 \pm 6.64$ \\
\hline 2 & $0.64 \pm 0.08$ & $0.62 \pm 0.07$ & $85.71^{\mathrm{a}}$ & $-22.05 \pm 6.00$ & $53.25 \pm 10.37$ & $-23.80 \pm 5.55$ \\
\hline 3 & $0.46 \pm 0.05$ & $0.47 \pm 0.06$ & $80.95^{\mathrm{b}}$ & $-28.95 \pm 12.88$ & $0.60 \pm 0.54$ & $-35.09 \pm 17.39$ \\
\hline 4 & $0.41 \pm 0.06$ & $0.45 \pm 0.15$ & $76.19^{\mathrm{a}}$ & No peak & No peak & No peak \\
\hline 5 & $0.36 \pm 0.10$ & $0.38 \pm 0.09$ & $57.14^{\mathrm{c}}$ & $"$ & $"$ & $"$ \\
\hline 6 & $0.34 \pm 0.07$ & $0.34 \pm 0.09$ & $61.90^{\mathrm{b}}$ & $"$ & $"$ & $"$ \\
\hline 7 & $0.30 \pm 0.05$ & $0.29 \pm 0.08$ & $47.62^{\mathrm{b}}$ & $"$ & $"$ & $"$ \\
\hline
\end{tabular}

DSC can be used to determine the unfrozen water content and the optimal moisture content for cryopreservation (Hamilton et al. 2009). The unfrozen water content of $C$. mollissima embryo is the $\mathrm{x}$-intercept of the regression lines of best fit of the embryo at the moisture contents, with the presence of the exothermic peak. Fig. 2 shows that the unfrozen water content of $C$. mollissima was determined as $0.247 \mathrm{gH}_{2} \mathrm{O} / \mathrm{g} \mathrm{dw}\left(\mathrm{R}^{2}=0.897\right)$. Theoretically, at the embryo moisture content of $0.247 \mathrm{gH}_{2} \mathrm{O} / \mathrm{g} \mathrm{dw}$, the embryo freezable water is no longer present.

Recalcitrant seeds conservation is a great challenge, the main reason is recalcitrant seeds are desiccation sensitive, removal of bound water will lead viability loss (Xia et al. 2012, Jin et al. 2018). Xia (2014) compared four Quercus species recalcitrant embryonic axes and reported that avoid of freezing was more important than drought for increase desiccation tolerance. The present study showed that $C$. mollissima has desiccation sensitive seeds, $0.29 \mathrm{gH}_{2} \mathrm{O} / \mathrm{g}$ dw embryos moisture content with survival percentage droping to 47.6, however, the unfrozen water content was $0.247 \mathrm{gH}_{2} \mathrm{O} / \mathrm{g} \mathrm{dw}$. This means dehydration of the embryos to unfrozen water content will kill most of the embryonic axes. Corredoira (2004) reported European chestnut (C. sativa Mill.) embryonic axes rendering damage (only root growth) after cryostorage when moisture contents was less than $19 \%$, it is similar with C. mollissima, their embryos semi-lethal moisture content was below $0.29 \mathrm{gH}_{2} \mathrm{O} / \mathrm{g} \mathrm{dw}$.

This study showed that the embryos moisture content decreased in different ratios when dried for different days (Table 1), presumably due to different types of water in the embryonic axes. As 
Zoubi (2015) used DSC analyzed Fortunella polyandra embryonic axes water and named four types of water in the embryonic axes, which were sharp peak water, broad peak water, unfrozen water and non-freezable/unfreezable water. However, some researchers thought that sharp peak water has commonly been found in immature axes (Wesley-Smith et al. 1992, Farrant and Walters 1998). Wolfe (2002) considered unfrozen and unfreezable water to be in one category. This study showed that $C$. mollissima embryonic axes also have different types of water, sharp peak water and broad peak water. The peak water produced water phase transition (freezing of ice) in the cooling thermograms, which lead to freezing injury to cell and tissue. Wild C. mollissima embryonic axes have peak water at the embryo moisture content of $0.47 \mathrm{gH}_{2} \mathrm{O} / \mathrm{g}$ dw or greater, with embryonic axes dried in silica gel for 3 days or less. Removal of all the peak water is necessary for $C$. mollissima seeds and embryonic axes cryopreservation. Cooling rate will also affect the thermogram, probably faster cooling will be able to eliminate the exothermic peak. And cryo-protectants can also be considered for cryopreservation of embryonic axes if seed viability is not so satisfactory below a certain moist content.


Fig. 1. Thermograms of Castanea mollissima embryonic axes desiccated different days.

$(0,1,2,3,4,5,6$ and 7 day). The cooling crystallisation was from right to left. 
Differential scanning calorimetry (DSC) is a useful tool to analyze embryo water thermodynamic change (Hor et al. 2005, Nadarajan et al. 2008). From the DSC analyses of $C$. mollissima embryonic axes, there are three key points for the embryonic axes desiccation: (a) exothermic peak; (b) unfrozen water content, ans (c) onset temperature. Crystallization peak during the cooling process of $C$. mollissima means freeze injury to its embryonic axes tissue, so wild $C$. mollissima embryonic axes need to be dried to less than $0.47 \mathrm{gH}_{2} \mathrm{O} / \mathrm{g}$ dw moist content, in



Fig. 2. The mean enthalpies of the freezing transition in Castanea mollissima embryonic axes at different moisture content. " $\mathrm{x}$ " intercept $=0.247 \mathrm{gH}_{2} \mathrm{O} / \mathrm{g} \mathrm{dw}$.

order to avoid the crystallization peak. Although dried C. mollissima embryonic axes to unfrozen water content is logically ideal condition, it means the embryonic axes viability loss to some extent. In conclusion, C. mollissima embryonic axes desiccation need comprehensive consideration of crystallization peak, unfrozen water content, onset temperature and viability loss. With $76.19 \%$ embryonic axes survival rate, $0.45 \mathrm{gH}_{2} \mathrm{O} / \mathrm{g} \mathrm{dw} \mathrm{mc}$ is considered to be the optimal embryo moisture content for seeds of wild C. mollissima. Above $0.45 \mathrm{gH}_{2} \mathrm{O} / \mathrm{g}$ dw embryo moisture content, it is also potential freezer storage of $C$. mollissima seeds and embryos, which need storage the seed in higher temperature environment than the onset temperature to avoid freezing injury.

\section{Acknowledgments}

This study was financially supported by National Key Research and Development Plan "Screening of Ecological and Economical Varieties of Chinese Chestnut and Supporting Cultivation Technology"(2019YFD1001604) and Shandong Provincial Agricultural Elite Varieties Project "Research on key techniques for conservation of wild forest species in germplasm bank" (2019LZGC01801).

\section{References}

Corredoira E, San-Jose MC, Ballester A and Vieitez AM 2004. Cryopreseravtion of zygotic embryo axes and somatic embryos of European chestnut. Cryo. Letters 25: 33-42.

Farrant JM and Walters C 1998. Ultrastructural and biophysical changes in developing embryos of Aesculus hippocastanum in relation to the acquisition of tolerance to drying. Physiol. Plant. 104: 513-524. 
Hamilton KN, Ashmore SE and Pritchard HW 2009. Thermal analysis and cryopreservation of seeds of Australian wild Citrus species (Rutaceae): Citrus australasica, C. inodora and C. garrawayi. Cryo. Letters 30: 268-279.

Hor YL, Kim YJ, Ugap A, Chabrillange N, Sinniah UR, Engelmann F and Dussert S 2005. Optimal hydration status for cryopreservation of intermediate oily seeds: Citrus as a case study. Ann. Botany 95 : 1153-1161.

Jin XF, Liu DD, Ma LL, Gong ZM, CaoD, Liu YL, Li YY and Jiang CJ 2018. Transcriptome and expression profiling analysis of recalcitrant tea (Camellia sinensis L.) seeds sensitive to dehydration. Int. J. Genomics 1-11. <https://doi.org/10.1155/2018/5963797>

Lehner A, Corbineau F and Bailly C 2006. Changes in lipid status and glass properties in cotyledons of developing sunflower seeds. J. Plant Physiol. 47: 818-828.

Li DZ and Pritchard HW 2009. The science and economics of ex situ plant conservation. Trends Plant Sci. 14 (11): 614-621.

Nadarajan J, Mansor M, Krishnapillay B, Staines HJ, Benson EE and Harding K 2008. Applications of differential scanning calorimetry in developing cryopreservation strategies for Parkia speciosa, a tropical tree producing recalcitrant seeds. CryoLetters 29: 95-110.

Serdar U, Demirsoy H and Demirsoy L 2011. A morphological and phonological comparison of chestnut (Castanea) cultivars 'Serdar' and 'Marigoule'. Aust. J. Crop Sci. 5: 1311-1317.

Walters C, Berjak P, Pammenter N, Kennedy K and Raven P 2013. Preservation of recalcitrant seeds. Science 339: $915-916$.

Walters C, Wheeler L and Grotenhuis M 2005. Longevity of seeds stored in gene bank: species characteristics. Seed Sci. Res. 15: 1-20.

Wesley-Smith J, Vertucci CW, Berjak P, Pammenter NW and Crane J 1992. Cryopreservation of desiccationsensitive axes of Camellia sinensis in relation to dehydration, freezing rate, and the thermal properties of tissue water. J. Plant Physiol. 140: 596-604.

Wolfe J, Bryant G and Koster KL 2002. What is 'unfreezable water', how unfreezable is it and how much is there? CryoLetters 23: 157-166.

Xia K, Daws MI, Stuppy W and Pritchard HW 2012. Rates of water loss and uptake in recalcitrant fruits of Quercus species are determined by pericarp anatomy. Plos One 7: 1-11.

Xia K, Hill LM, Li DZ and Walters C 2014. Factors affecting stress tolerance in recalcitrant embryonic axes from seeds of four Quercus (Fagaceae) species native to the USA or China. Ann. Botany 114: 1747-1759.

Zong M and Cai YP 2010. Desiccation sensitivity of C.mollissima seeds at different developmental stages. Journal of Northeast Forestry University (in Chinese) 38: 21-23.

Zou F, Guo SJ, Xiong H, Wang J, Zhang XN, Peng JJ and Peng YQ 2015. Effects of different pollination treatments on nutrition changes of the ovary in Chinese chestnut ( $C$. mollissima Blume). Adv. J. Food Sci. Technol. 8: 157-162.

Zoubi OMA and Normah MN 2015. Critical moisture content for successful cryopreservation of embryonic axes of Fortunella polyandra determined by differential scanning calorimetry (DSC). Acta Physiol. Plant. 37: 17-27. 